\title{
PENDIDIKAN KEBUTUHAN KHUSUS DITINJAU DARI PERSPEKTIF PSIKOLOGI PERKEMBANGAN
}

\author{
${ }^{1}$ Hikmah Ayu Maulidiyah \\ ${ }^{2}$ Nono Hery Yoenanto \\ Fakultas Psikologi Universitas Airlangga \\ hikmah.ayu.maulidiyah-2014@psikologi.unair.ac.id
}

\begin{abstract}
ABSTRAK
Tujuan penelitian ini adalah meninjau peran dari pendidikan bagi anak berkebutuhan khusus dari perspektif psikologi perkembangan. Selaras degan prinsip psikologi yang memiliki kontribusi penting untuk memahami, memaparkan, memprediksi, mengontrol, dan memecahkan masalah anak berkebutuhan khusus. Penelitian ini merupakan jenis penelitian kualitatif dengan metode deskriptif. Strategi pengumpulan data pada penelitian ini adalah studi dokumentasi. Analisis data penelitian ini yaitu: (1) reduksi data; (2) penyajian data; dan (3) verifikasi data. Hasil penelitian ini adalah peran penting psikologi dalam memahami, menjelaskan, memprediksi, mengontrol, dan memecahkan masalah anak berkebutuhan khusus. Kolaborasi kelompok akan memberikan dampak yang optimal untuk membantu anak berkebutuhan khusus mengembangkan kemampuan atau kecakapan hidupnya di lingkungan fisik, sosial, dan spiritualnya. Psikolog menerapkan teori psikologi dalam memahami, menjelaskan, memprediksi, mengontrol, dan memecahkan masalah anak berkebutuhan khusus. Teori perkembangan psikologi perkembangan menerapkan teori dan praktik perkembangan kognitif, afektif, moral, sosial, dan fisik anak dengan kebutuhan khusus.
\end{abstract}

Kata kunci: pendidikan, anak kebutuhan khusus, psikologi perkembangan.

\begin{abstract}
The purpose of this study is to investigate the educational role of children in need of special needs from a developmental perspective. According to psychological principles that make an important contribution to understanding, explaining, predicting, controlling, and solving the problems of children with special needs. This study is a kind of qualitative study by a descriptive method. The data collection strategy for this study is a documented study. The data analysis for this study is as follows: (1) Data reduction. (2) Presentation of data. (3) Data review. Research results play an important role in psychology in understanding, explaining, predicting, controlling, and solving problems in children with special needs. Teamwork is ideally effective in helping children with special needs develop their skills and life skills in a physical, social, and mental environment. Psychologists apply psychological theory to understand, explain, predict, control, and solve problems faced by children with special needs. Developmental Psychology's Developmental Theories apply cognitive, emotional, moral, physical, and social developmental theories and practices to children with special needs.
\end{abstract}

Keywords: education, special needs children, developmental psychology.

\section{PENDAHULUAN}

Anak berkebutuhan khusus meliputi anak-anak seperti: (1) Cacat intelektual yang berkembang lebih lambat dari anak-anak lain. (2) Berikut gangguan bahasa dan gangguan bahasa berupa masalah dalam mengekspresikan diri dan memahami orang lain. (3) Cacat fisik seperti gangguan penglihatan, cerebral palsy, atau kondisi lainnya. (4) Ketidakmampuan belajar yang 
mendistorsi pesan dari indera. (5) Gangguan emosional seperti antisosial atau masalah perilaku lainnya (Jamaica Hearing Impaired Persons Association, 2015). Kekhawatiran orang tua yang umum termasuk, tetapi tidak terbatas pada, anak-anak yang tidak menyukai anak-anak yang sehat, pengalaman buruk dengan anak-anak sebelumnya yang dapat mempengaruhi mereka, dan kemungkinan faktor risiko. Faktor risiko tersebut dapat terjadi selama kehamilan, persalinan, atau setelah anak lahir. Faktor risiko tersebut dilindungi oleh semua pihak, terutama pendidik, untuk memastikan deteksi dini agar tidak terjadi kesalahan dalam memberikan stimulasi atau intervensi pada anak, terutama ketika ada kebutuhan khusus lainnya. Harus diperhatikan oleh orang tersebut. Menurut survei di Amerika, 18,5\% anak-anak Amerika di bawah usia 18 tahun adalah anak-anak berkebutuhan khusus. Itu tidak berarti mereka cerdas, tidak berbakat, dan tidak kompeten. Mereka hanya menghadapi tantangan khusus yang tidak dihadapi anak-anak "biasa". Angka ini menunjukkan bahwa Amerika Serikat memiliki banyak anak berkebutuhan khusus, dan hasil ini penting bagi pemerintah dalam hal deteksi dini anak berkebutuhan khusus (Viramitha, 2016).

Era kini, dalam deteksi anak kebutuhan khusus, peran psikolog telah berubah secara mendasar selama 35 tahun terakhir. Mengikuti Commission of Inquiry on Mental Handicap (1965) dan perluasan penyediaan spesialis, peran penilaian psikologis dalam identifikasi dan penempatan anak-anak dengan ketidakmampuan belajar menjadi sangat penting. Oleh karena itu secara tradisional, penilaian psikologis terutama digunakan untuk membantu dalam diagnosis anak-anak. Penilaian ini pada gilirannya berkontribusi pada keputusan tentang sekolah dan penempatan kejuruan. Namun jenis penilaian psikologis ini dan ketergantungan pada alat psikometri khususnya, memiliki kegunaan yang terbatas untuk mengidentifikasi kebutuhan sehari-hari anak di sekolah atau di keluarga. Jelas sejak saat itu bahwa model penilaian diagnostik tidak mencerminkan totalitas anak. Peran psikolog telah bergerak menuju model sistemik dan kolaboratif. Ini berarti bahwa psikolog terlibat dalam proses kolaboratif dengan orang-orang dalam sistem biopsikososial anak yaitu anak, guru dan sistem pendidikan, keluarga dan masyarakat bersama dengan profesional lain yang terlibat dengan anak.

Di dunia global kita, ada fenomena anak berkebutuhan khusus. Di Indonesia, beberapa anak memiliki kebutuhan khusus. Anak berkebutuhan khusus adalah anak dengan keterbelakangan kognitif, emosional, dan psikomotorik. Fenomena anak berkebutuhan khusus meliputi anak autis, anak dengan gangguan jiwa, anak dengan gangguan pemusatan perhatian dan hiperaktif, serta anak dengan gangguan sensorik, fisik dan kesehatan. Karena keterbatasan (kognitif, afektif, dan psikomotor) mereka harus didukung untuk menyesuaikan diri dengan lingkungan spiritual, sosial, dan fisik mereka. Dalam konteks ini, masyarakat dan komunitas di mana mereka tinggal harus mendukung mereka agar anak-anak dapat hidup bahagia dan kaya. Dukungan tersebut dapat diwujudkan melalui pendidikan bagi anak berkebutuhan khusus.

Dukungan pendidikan keluarga, sekolah, dan masyarakat terhadap anak berkebutuhan khusus relevan dengan ideologi dasar Indonesia, yaitu Pancasila adalah tentang Indonesia sebagai negara kaya. Pancasila, menyatakan bahwa setiap warga 


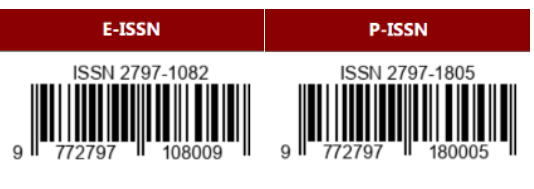

negara Indonesia berhak untuk menjustifikasi keadilan sosial dalam kehidupannya. Pemenuhan hak dapat membuat mereka mencapai kesejahteraan atau kebahagiaan subjektif mereka dan juga mencapai fungsi positif (Baumgardner \& Crothers, 2010). Pemenuhan hak-hak anak berkebutuhan khusus melalui pendidikan juga dapat dilihat sebagai perwujudan dari tag negara Indonesia, yaitu Bhinneka tunggal ika, sebagai simbol dasar negara Indonesia sebagai masyarakat multikultural. Dalam konteks ini, kita dapat melihat bahwa kelompok anak berkebutuhan khusus merupakan salah satu kelompok budaya dari berbagai kelompok yang hidup di Indonesia. Salah satu cara keluarga, sekolah, masyarakat, dan sekolah untuk memfasilitasi anak berkebutuhan khusus adalah pengetahuan dan praktik tentang perspektif psikologi terhadap anak berkebutuhan khusus. Psikologi sebagai ilmu tentang perilaku dan fenomena mental dapat membantu melalui teori dan praktik untuk membantu anak berkebutuhan khusus menyesuaikan diri dengan lingkungannya. Efektivitas penyesuaian diri dapat membantu mereka dalam memperoleh kebahagiaan dan memenuhi fungsinya dalam keluarga, sekolah, masyarakat, dan negara.

Tujuan penelitian ini adalah meninjau peran dari pendidikan bagi anak berkebutuhan khusus dari perspektif psikologi perkembangan. Selaras degan prinsip psikologi yang memiliki kontribusi penting untuk memahami, menjelaskan, memprediksi, mengontrol, dan memecahkan masalah anak berkebutuhan khusus. Sehingga, berdasarkan paparan latar belakang di atas, peneliti tertarik untuk membahas mengenai, "Pendidikan Kebutuhan Khusus Ditinjau dari Perspektif Psikologi Perkembangan.”

\section{MET ODE}

\section{Desain Penelitian}

Penelitian ini merupakan jenis penelitian kualitatif. Menurut Cresswell (2016), penelitian kualitatif adalah studi menyelidiki dan memahami makna individu atau kelompok orang yang berbeda karena masalah sosial. Penelitian kualitatif umumnya digunakan sebagai penelitian tentang kehidupan, masyarakat, sejarah, perilaku, konsep, atau fenomena. Alasan dipilihnya jenis penelitian ini adalah untuk menemukan dan memahami apa yang melatarbelakangi fenomena yang sulit dipahami tersebut.

Metode penelitian ini adalah deskriptif. Metode ini disusun berdasarkan filsafat postpositivisme untuk meneliti kondisi objek secara alamiah dimana peneliti sebagai instrument kunci. Tujuan penelitian deskriptif bertujuan untuk menggambarkan, melukiskan, menerangkan, menjelaskan, dan menjawab permasalahan yang akan diteliti.

\section{Partisipan}

Profil partisipan dalam penelitian ini adalah anak-anak dengan kebutuhan khusus yang membutuhkan penanganan secara psikologis.

\section{Strategi Pengumpulan Data}

Strategi pengumpulan data untuk penelitian ini adalah studi terdokumentasi. Menurut Sugishirono (2016), dokumen merupakan catatan peristiwa masa lalu. Dokumen tersebut dapat berupa teks, foto, atau karya monumental seseorang. Dokumen yang digunakan dalam karya ilmiah ini adalah jurnal dan buku yang sesuai dengan topik survei dan direduksi menjadi titik data yang sesuai.

\section{Analisis Data}


Analisis data untuk penelitian ini adalah sebagai berikut: (1) Reduksi data. (2) Penyajian data. (3) Peninjauan data. Pertama, mereduksi atau meringkas data yang diperoleh dengan memilih fokus sesuai dengan tema penelitian. Kedua, data direpresentasikan dengan pola hubungan yang lebih mudah dipahami. Terakhir, kita akan mengkaji apakah kita dapat menarik kesimpulan berupa kausalitas yang masih bersifat sementara. Dapat berubah jika tidak ditemukan bukti yang kuat pada tahap pengumpulan data penelitian selanjutnya.

\section{HAS IL PENELITIAN}

\section{Anak Kebutuhan Khusus}

Anak berkebutuhan khusus dapat didefinisikan sebagai anak yang memiliki disabilitas, kondisi kesehatan atau kesehatan mental yang memerlukan, intervensi dini yang memerlukan intervensi dan dukungan dini. Disabilitas merupakan keterbatasan fungsi kemampuan kognitif, afektif, dan psikomotorik. Dalam bidang pendidikan, anak berkebutuhan khusus dapat didefinisikan sebagai anak yang memiliki fungsi kognitif, afektif, dan fisik yang sangat berbeda dari biasanya sehingga diperlukan perlakuan tambahan untuk memenuhi kebutuhan anak tersebut (Slavin, 2006). Ada beberapa jenis anak berkebutuhan khusus. Beberapa jenis anak berkebutuhan khusus dapat didaftar sebagai berikut: anak autis, anak dengan keterbelakangan mental, anak dengan gangguan pemusatan perhatian, dan anak dengan gangguan sensorik, fisik, dan ganggungan kesehatan mental.

Anak dengan Autisme perlu mendapat perhatian khusus. Autisme adalah penyerapan diri patologis dan keasyikan dengan diri untuk mengesampingkan dunia luar (Colman, 2006). Autisme adalah gangguan perkembangan yang sangat mempengaruhi interaksi sosial dan komunikasi (Slavin, 2006). Autisme menjadi kategori formal kecacatan atau kebutuhan khusus pada tahun 1990. Anak autisme ditandai dengan kesulitan dalam mengembangkan interaksi sosial, kesulitan dalam mengembangkan komunikasi sosial (verbal dan nonverbal) dan komunikasi interpersonal, dan kecenderungan untuk terlibat dalam perilaku berulang.

Gejala autisme muncul pada masa bayi dan anak usia dini. Ini dapat menunda banyak bidang dasar perkembangan, terutama dalam keterampilan sosial atau hubungan manusia seperti belajar berkomunikasi, bermain, dan berinteraksi dengan orang lain. Meskipun beberapa kesulitan sosial, anak autis mungkin memiliki kompetensi yang normal atau luar biasa dalam bidang tertentu (Slavin, 2006). Meskipun autisme umumnya merupakan kondisi seumur hidup, anak-anak dengan autisme dapat memperoleh manfaat dari terapi atau intervensi yang dapat mengurangi gejala dan meningkatkan keterampilan dan kemampuan sosial. Ini dapat membantu mereka hidup di lingkungan sosial mereka. Pendidik dan psikolog dapat membantu mereka dengan intervensi dan terapi sesegera mungkin.

Anak-anak dengan keterbelakangan mental. Anak tunagrahita adalah anak yang memiliki keterbatasan substansial dalam fungsinya saat ini. Keterbatasan substansial dalam bidang keterampilan adaptif sebagai berikut: komunikasi, perawatan diri, keterampilan sosial, komunikasi, penggunaan masyarakat, kehidupan di rumah, akademik fungsional, waktu luang dan pekerjaan, dll. Gejala keterbelakangan mental dapat dikenali sebelum usia 18 tahun. Ada klasifikasi anak tunagrahita berdasarkan nilai IQnya. Klasifikasi tersebut dapat didaftar sebagai: (1) 
Anak-anak dengan keterbelakangan ringan (IQ 55 hingga 70), mereka dianggap "dapat dididik"; (2) Anak-anak dengan keterbelakangan sedang (IQ sekitar 55), mereka dianggap "dapat dilatih"; (3) Anakanak dengan keterbelakangan "penahanan" (IQ di bawah 50), mereka adalah layanan di luar sekolah (Slavin, 2006).

Secara umum, pendidik perlu membantu anak tunagrahita memperoleh keterampilan perilaku adaptif (Slavin, 2006). Anak-anak dengan gangguan pemusatan perhatian dan gangguan hiperaktif. Anak dengan attention deficit hyperactivity disorder adalah anak yang mengalami kesulitan mempertahankan perhatian karena konsentrasi yang buruk. Perhatian anak dengan gangguan hiperaktif defisit memiliki ciri-ciri: (a) defisit perhatian; (b) perilaku impulsif; (c) hiperaktif perilaku. Dalam pengaturan pendidikan, anak dengan gangguan hiperaktif defisit perhatian mungkin memiliki signifikan akademik, perilaku, dan masalah sosial sebagai akibat dari ketidakmampuan mereka untuk berkonsentrasi atau memperhatikan. Gangguan jiwa ini ditandai dengan kurangnya perhatian dan impulsif yang terus-menerus dengan beberapa gejala muncul sebelum usia 7 tahun, menyebabkan masalah di rumah dan sekolah. Gangguan mental masa kanak-kanak mempengaruhi antara dua atau sepuluh persen anak usia sekolah di dunia (Slavin, 2006).

Anak tunagrahita, fisik, dan kesehatan meliputi anak tunarungu, anak tunagrahita, anak gangguan kesehatan. Anak tunagrahita adalah anak yang memiliki masalah dengan kemampuan mendengar atau melihat informasi melalui indera tubuh. Contoh anak tunarungu adalah anak tunanetra atau anak tunarungu atau tunarungu. Anak tunagrahita adalah anak yang mengalami gangguan fisik seperti cedera tulang belakang, palsi serebral, dan distrofi otot. Anak dengan gangguan kesehatan adalah anak yang mengalami gangguan kesehatan, antara lain Acquired Immune Deficiency Syndrome (AIDS), diabetes, child abuse, percobaan bunuh diri, dan lain-lain (Slavin, 2006). Di bidang pendidikan, pendidik harus membantu mereka dengan beberapa perawatan atau strategi pembelajaran sehingga mereka dapat belajar dengan baik di kelas dan sekolah.

\section{Psikologi}

Hanurawan (2015) mendefinisikan psikologi sebagai studi ilmiah tentang fenomena perilaku dan proses mental manusia. Kajian ilmiah psikologi mencakup segala sesuatu yang orang (kognitif), rasakan (afektif), dan lakukan (perilaku). Tujuan psikologi adalah untuk mendeskripsikan, menjelaskan, mengendalikan, dan memecahkan masalah terhadap fenomena mental dan perilaku. Fenomena tersebut dapat dirinci pada fenomena seperti persepsi, perkembangan manusia, sikap, motivasi, dll. Sebagai kajian ilmiah, psikologi memiliki beberapa metode untuk mendeskripsikan objek-objek psikologi (kognitif, afektif, dan perilaku).

Secara umum, metode yang akrab dengan psikologi adalah pendekatan positivistik, interpretatif, dan kritis (Hanurawan, 2010). Pendekatan positivistik juga dapat disebut sebagai pendekatan penelitian kuantitatif. Rancangan pendekatan positivistik adalah eksperimen laboratorium, eksperimen lapangan, dan korelasi lapangan. Instrumen pendekatan positivistik adalah observasi terstruktur, angket, penilaian psikologi, dan lain-lain. Data yang terkumpul dianalisis dengan teknik statistik seperti uji-t, analisis korelasi, model persamaan 
terstruktur, analisis jalur, dan analisis regresi berganda. Pendekatan interpretatif juga bisa disebut sebagai pendekatan kualitatif. Model atau desain pendekatan tersebut adalah studi kasus, fenomenologi, hermeneutik, dan metodologi etno (Hanurawan, 2016a). Metode pengumpulan data dalam penelitian kualitatif adalah observasi tidak terstruktur atau observasi partisipan, dokumen, kuesioner kualitatif, dan jurnal refleksi tertulis. Data yang terkumpul dalam penelitian kualitatif dianalisis menggunakan analisis isi, analisis deskriptif, analisis tematik, dan analisis fenomenologis. Proses validasi dalam penelitian kualitatif menggunakan beberapa metode, seperti triangulasi atau member check. Ada bidang utama dalam psikologi. Bidang-bidang tersebut adalah Psikologi Sosial, Psikologi Klinis, Psikologi Pendidikan, Psikologi Perkembangan, Psikologi Organisasi dan Industri. Psikologi sosial. Psikologi sosial adalah bidang psikologi yang dikhususkan untuk perilaku sosial. Objek yang dipelajari dalam psikologi sosial meliputi konformitas, perilaku agresi, sikap sosial, perilaku kolektif hubungan dekat, keterampilan sosial, dan lain-lain. Berikutnya, psikologi klinis adalah bidang psikologi yang berkaitan dengan sifat, diagnosis, klasifikasi, pengobatan, dan pencegahan "gangguan mental dan cacat" (Colman, 2006).

Psikologi pendidikan adalah bidang psikologi yang berkaitan dengan dinamika psikologis dalam setting pendidikan (Colman, 2006). Topik psikologi pendidikan meliputi pengembangan manusia yang berkaitan dengan pendidikan, keragaman anak, pembelajaran, pengajaran yang efektif, kreativitas dalam pendidikan, motivasi dalam pendidikan, peserta didik dengan keistimewaan, evaluasi, dll. Pembangunan psikologi adalah studi ilmiah psikologi terhadap perubahan manusia selama hidup mereka. Topik psikologi perkembangan adalah kontroversi antara alam dan pengasuhan, perkembangan kognitif, perkembangan sosial dan emosional, perkembangan fisik, perkembangan moral, perkembangan masa kanak-kanak, perkembangan masa kanak-kanak, perkembangan remaja, perkembangan dewasa, dan perkembangan usia tua, dan pengasuhan.

Psikologi organisasi dan industri. Psikologi organisasi dan industri adalah bidang psikologi tentang perilaku manusia dan proses mental dalam pengaturan organisasi dan industri. Topik psikologi organisasi dan industri meliputi remunerasi dan kompensasi, motivasi dalam organisasi dan industri, stres kerja, budaya organisasi, rekayasa faktor manusia atau ergonomis, kepuasan kerja, perilaku kewarganegaraan organisasi, kepemimpinan, analisis pekerjaan, rekrutmen dan seleksi personel, dan pelatihan. Selain bidang-bidang utama psikologi, ada juga banyak bidang atau subbidang psikologi yang spesifik. Bidang khusus psikologi termasuk ergonomis, psikologi lingkungan, psikologi komunitas, psikologi forensik, psikologi belajar, psikologi konseling, psikologi kelompok, psikologi motivasi, dan lain-lain.

\section{I S K US I}

Anak berkebutuhan khusus adalah mereka yang berkebutuhan khusus berbeda dengan anak "normal" lainnya. Berbagai kondisi tersebut sering disebut sebagai disabilitas. Menurut pendapat Havighurst, "normal" dapat dilihat secara biologis, sosial dan pribadi. Efendi (2006) juga menemukan bahwa kategori anak berkebutuhan khusus 


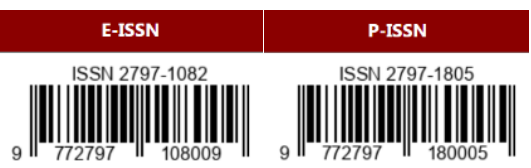

dapat dilihat dari segi fisik, mental dan sosial. Aspek fisik meliputi gangguan penglihatan, gangguan pendengaran, gangguan bicara, dan kelumpuhan (disability). Aspek mental meliputi bakat dan disabilitas intelektual. Aspek sosial termasuk tuna. Tunanetra adalah gangguan pada organ penglihatan atau mata yang membuat anak tidak dapat melihat benda-benda di sekitarnya. Gangguan pendengaran adalah gangguan pendengaran atau telinga yang membuat anak tidak dapat mendengar atau mendengar kebisingan sekitar. Gangguan bicara adalah kelainan pada arti pengucapan yang menghalangi seorang anak untuk berbicara. Tetraplegia adalah ketidakmampuan seorang anak untuk bergerak karena kurangnya sistem motorik seperti anak. Keterbelakangan mental adalah suatu kondisi yang menunjukkan kecerdasan mental yang tidak normal. Tuna laras adalah kemampuan seorang anak untuk tidak dapat menyesuaikan perilaku sosialnya sehingga tidak dapat beradaptasi. Handojo (2003) menemukan bahwa jenis anak berkebutuhan khusus yang paling parah dan umum adalah autisme bayi, sindrom Asperger, gangguan pemusatan perhatian (hiperaktivitas) atau $\mathrm{AD}(\mathrm{H}) \mathrm{D}$. Ia menambahkan bahwa ia mengalami keterlambatan, disleksia, dan disleksia. Autisme bayi adalah kelainan pada anak yang seolah-olah memiliki kehidupannya sendiri. Sindrom Asperger mengacu pada gangguan seperti autisme pada bayi, di mana anak-anak mengalami kesulitan bersosialisasi tetapi pandai berkomunikasi. Gelfand \& Drew berasumsi bahwa gangguan Asperger ditandai dengan gangguan serius dalam interaksi sosial yang terkait dengan perkembangan pola perilaku dan aktivitas yang khas. $\mathrm{AD}(\mathrm{H}) \mathrm{D}$ merupakan gangguan dimana perilaku motorik yang terlalu aktif dan konsentrasi atau gangguan konsentrasi.
Keterlambatan bicara adalah keterlambatan dalam memproduksi kata-kata anak. Disleksia adalah gangguan perkembangan bahasa. Dispraksia adalah gangguan dalam koordinasi gerakan.

Psikologi memiliki kontribusi penting untuk memahami, menjelaskan, memprediksi, mengontrol, dan memecahkan masalah anak berkebutuhan khusus. Kontribusi nyata dari psikologi adalah dalam proses kolaboratif dengan pemangku kepentingan lain dalam sistem biopsiko-sosial anak. Sistem tersebut melibatkan anak, keluarga, masyarakat, pendidik dan sistem pendidikan, serta profesional lainnya. Dalam konteks ini, kontribusi psikolog paling baik diberikan dalam kelompok multi-disiplin (Feehan et al, 2003). Kolaborasi kelompok akan memberikan dampak yang optimal untuk membantu anak berkebutuhan khusus mengembangkan kemampuan atau kecakapan hidupnya di lingkungan fisik, sosial, dan spiritualnya. Deteksi dini dapat dilakukan dengan teknik dan tes nontes. Non-tes biasanya dilakukan secara informal, sedangkan tes biasanya dikenal secara formal. Reid (2011) menyatakan bahwa seringkali deteksi informal dapat menjadi langkah pertama dalam diagnosis. Dalam banyak hal, penilaian informal dapat menghasilkan informasi yang lebih berguna dan lebih rinci daripada penilaian standar formal. Salah satu poin kuat yang mendukung penilaian informal adalah penilaian tersebut dapat dilihat sebagai dinamis. Namun seseorang seringkali dapat memperoleh banyak informasi tentang anakanak, kebiasaan belajar mereka, dan preferensi dari penilaian informal dan beberapa informasi ini mungkin tidak mudah diperoleh dari penilaian formal dan standar.

Psikolog menerapkan teori psikologi dalam memahami, menjelaskan, 
memprediksi, mengontrol, dan memecahkan masalah anak berkebutuhan khusus. Bagi psikolog terapan, teori merupakan alat penting untuk memahami, menjelaskan, memprediksi, mengendalikan, dan memecahkan masalah anak berkebutuhan khusus. Teori-teori dalam psikologi dapat dilihat sebagai titik awal untuk melakukan pencegahan dan intervensi. Teori psikologi adalah seperangkat prinsip terorganisir yang menggambarkan, menjelaskan, dan memprediksi fenomena psikologis (kognitif, afektif, dan psikomotorik) (Schultz \& EstradaHollenbeck, 2008). Teori psikologi dapat dijadikan landasan bagi upaya kita untuk mengubah atau memecahkan perilaku anak berkebutuhan khusus. Contoh teori psikologi adalah teori belajar sosial, teori behavioris, teori kognitif, teori humanistik, teori psikoanalisis, dan teori kritikal (Hanuwaran, 2010).

Teori-teori psikologi yang dapat diterapkan pada anak berkebutuhan khusus dapat ditarik dan dikembangkan dari bidangbidang psikologi. Konsisten dengan keberadaan bidang-bidang utama psikologi, kajian anak berkebutuhan khusus dari perspektif psikologi dapat dilihat dari lima bidang psikologi, yaitu perspektif psikologi sosial, perspektif psikologi klinis, psikologi perkembangan, psikologi industri dan organisasi, dan psikologi pendidikan.

Pada bahasan ini, melalui teori dan praktik psikologi sosial, para psikolog dan pendidik dapat mengembangkan anak berkebutuhan khusus dengan keterampilan interpersonal dan sosial. Keterampilan interpersonal dan sosial meliputi persepsi interpersonal dan sosial, komunikasi interpersonal dan sosial, sikap sosial, memantau dan mengendalikan perilaku agresi dan kemarahan, keterampilan perilaku kewarganegaraan untuk hidup dalam kelompok, organisasi, dan komunitas, dan keterampilan hidup menyelesaikan konflik interpersonal dan sosial. Keterampilan sosial sangat penting bagi anak berkebutuhan khusus karena melalui keterampilan tersebut mereka memiliki kemampuan untuk bersosialisasi atau mengintegrasikan mereka ke dalam konteks sosial, seperti keluarga, sekolah, masyarakat, dan negara.

Melalui teori dan praktik psikologi klinis, para psikolog dan pendidik dapat mengembangkan kesehatan mental anak berkebutuhan khusus yang baik. Psikolog mengembangkan kesehatan mental melalui intervensi seperti penilaian, konsultasi klinis, dukungan perilaku positif, terapi, fasilitasi dukungan keluarga, dan hubungan dengan badan hukum dan sukarela (Feehan et al, 2003). Kesehatan mental yang baik sangat penting bagi anak berkebutuhan khusus, oleh karena itu mereka harus mengembangkan strategi untuk menghadapi situasi sulit dan metode pemecahan masalah secara tepat. Masalah kesehatan mental anak berkebutuhan khusus dapat didaftar sebagai berikut: kecemasan, depresi, penyakit mental yang serius (Better, 2016). Masalah kesehatan mental lainnya adalah kesepian, konsep diri rendah, dan harga diri rendah. Ada teori terapi yang dapat diterapkan pada kesehatan mental anak berkebutuhan khusus, misal terapi perilaku kognitif, terapi perilaku dialektik, terapi psikodinamik, dan terapi humanistik. Praktik terapi psikologi klinis di era psikologi positif harus memperkenalkan dan mengembangkan konsep-konsep positif kepada anak berkebutuhan khusus, seperti kesejahteraan subjektif, harapan, optimisme, ketahanan, kebajikan, kebijaksanaan, spiritualitas, dan lain-lain (Baumgardner \& Crothers, 2010). 


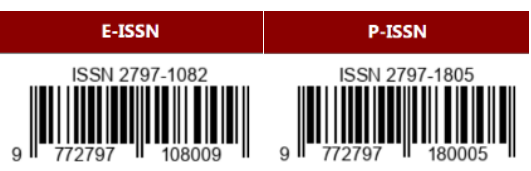

Teori perkembangan psikologi perkembangan menerapkan teori dan praktik perkembangan kognitif, afektif, moral, fisik, dan sosial pada anak berkebutuhan khusus. Teori-teori psikologi perkembangan meliputi teori Vygotsky, teori Piaget, teori Kohlberg, dan teori Freud. Psikolog perkembangan mengamati masalah perkembangan anak berkebutuhan khusus dan kemudian merekomendasikan pencegahan dan intervensi yang tepat terhadap masalah tersebut. Kontribusi ergonomis pada anak berkebutuhan khusus adalah melalui perancangan lingkungan fisik dan alat yang sesuai dengan karakteristik anak berkebutuhan khusus. Karakteristik tersebut meliputi psikologis, fisiologis, dan antropometrik. Ergonomis merancang produk khusus untuk anak berkebutuhan khusus, seperti kursi belajar khusus untuk anak berkebutuhan khusus. Desain yang tepat untuk anak berkebutuhan khusus diperlukan untuk mencegah cedera regangan berulang.

Teori dalam psikologi pendidikan dapat digunakan untuk membantu anak berkebutuhan khusus dalam bidang pendidikan, seperti di sekolah. Tugas utama guru adalah mengajar anak berkebutuhan khusus secara efektif, ada beberapa konsep umum pengajaran efektif untuk anak berkebutuhan khusus, antara lain: menekankan pencegahan, mengajarkan keterampilan belajar-belajar, sering memberikan umpan balik, menggunakan berbagai strategi mengajar yang melibatkan anak secara aktif dalam pelajaran, menggunakan metode manajemen kelas yang efektif, dan mengoordinasikan layanan tambahan dengan pengajaran saat kegiatan belajar mengajar di sekolahan.
Anak berkebutuhan khusus adalah mereka yang menderita cacat fisik, mental dan sosial. Tunanetra adalah gangguan pada organ penglihatan atau mata yang menyebabkan anak tidak dapat melihat benda-benda di sekitarnya. Gangguan pendengaran adalah gangguan pendengaran atau telinga yang membuat anak tidak dapat mendengar atau mendengar kebisingan sekitar. Gangguan bicara adalah kelainan pada arti pengucapan yang menghalangi seorang anak untuk berbicara. Tetraplegia adalah ketidakmampuan seorang anak untuk bergerak karena kurangnya sistem motorik seperti anak. Tuna laras adalah kemampuan seorang anak untuk tidak dapat menyesuaikan perilaku sosialnya sehingga tidak dapat beradaptasi.

Psikologi memiliki kontribusi penting untuk memahami, menjelaskan, memprediksi, mengontrol, dan memecahkan masalah anak berkebutuhan khusus. Kontribusi nyata dari psikologi adalah dalam proses kolaboratif dengan pemangku kepentingan lain dalam sistem biopsiko-sosial anak. Kolaborasi kelompok akan memberikan dampak yang optimal untuk membantu anak berkebutuhan khusus mengembangkan kemampuan atau kecakapan hidupnya di lingkungan fisik, sosial, dan spiritualnya. Dalam banyak hal, penilaian informal dapat menghasilkan informasi yang lebih berguna dan lebih rinci daripada penilaian standar formal. Salah satu poin kuat yang mendukung penilaian informal adalah penilaian tersebut dapat dilihat sebagai dinamis. Psikolog menerapkan teori psikologi dalam memahami, menjelaskan, memprediksi, mengontrol, dan memecahkan masalah anak berkebutuhan khusus. Bagi psikolog terapan, teori merupakan alat penting untuk memahami, menjelaskan, memprediksi, 
mengendalikan, dan memecahkan masalah anak berkebutuhan khusus.

Teori-teori dalam psikologi dapat dilihat sebagai titik awal untuk melakukan pencegahan dan intervensi. Teori psikologi dapat dijadikan landasan bagi upaya kita untuk mengubah atau memecahkan perilaku anak berkebutuhan khusus. Ada teori terapi yang dapat diterapkan pada kesehatan mental anak berkebutuhan khusus, misal terapi perilaku kognitif, terapi perilaku dialektik, terapi psikodinamik, dan terapi humanistik. Praktik terapi psikologi klinis di era psikologi positif harus memperkenalkan dan mengembangkan konsep-konsep positif kepada anak berkebutuhan khusus, seperti kesejahteraan subjektif, harapan, optimisme, ketahanan, kebajikan, kebijaksanaan, spiritualitas, dan lain-lain. Teori perkembangan psikologi perkembangan menerapkan teori dan praktik perkembangan kognitif, afektif, moral, fisik, dan sosial pada anak berkebutuhan khusus. Psikolog perkembangan mengamati masalah perkembangan anak berkebutuhan khusus dan kemudian merekomendasikan pencegahan dan intervensi yang tepat terhadap masalah tersebut. Kontribusi ergonomis pada anak berkebutuhan khusus adalah melalui perancangan lingkungan fisik dan alat yang sesuai dengan karakteristik anak kebutuhan khusus. Teori psikologi pendidikan dapat digunakan, misalnya, di sekolah untuk membantu anak berkebutuhan pendidikan khusus.

\section{UCAPAN TERIMA KASIH}

Puji syukur kehadirat Tuhan Yang Maha Esa atas rahmat dan kasih sayang yang tiada tara. Kami berterima kasih kepada orang tua dan semua yang terlibat atas dukungan materi dan moral sehingga kami dapat menyusun studi ini. Semoga pekerjaan ini bermanfaat bagi semua orang yang membutuhkan.

\section{DAFTAR PUSTAKA}

Baumgardner, S. R. \& Crothers, M. K. (2010). Positive Psychology. Upper Saddle River New York: Pearson Prentice Hall.

Better, O. N. D. (2016). Children and Young People with Learning Disabilities. Understanding Their Mental Health. London: Bond c/o Youngminds.

Colman, A. M. (2006). A Dictionary of Psychology. New York: Oxford University Press.

Commission of Inquiry on Mental Handicap. (1965). Commission of Inquiry on Mental Handicap. Stationery Office.

Creswell, Jhon W. (2016). Research Design: Pendekatan Kualitatif, Kuantitatif, dan Mixed. Yogyakarta: Pustaka Belajar.

Effendi, Muhammad. (2006). Psikopedagogik Anak Berkelainan. Jakarta: Bumi Aksara

Feehan, S., McCharty, Y., \& White, C. (2003). The role of psychologist with school age children with an intellectual disability. A brother of charity guidelines document for psychologist working in special schools in the southern services.

Handoko, T. Hani. (2003). Manajemen Sumber Daya Manusia. Yogyakarta: BPEF.

Hanurawan, F. (2010). Psikologi Sosial Suatu Pengantar. Bandung: Rosdakarya.

Hanurawan, F. (2015). Ilmu Psikologi untuk Pemecahan Masalah Kemanusiaan. Professorship Oration. Universitas Negeri Malang. 
Hanurawan, F. (2016a). Metode Penelitian

Kualitatif: Untuk Ilmu Psikologi.

Jakarta: PT Raja Grafindo Persada.

Hanurawan, F. (2016b). Perspektif Alternatif dalam Psikologi Pendidikan. Malang: Universitas Negeri Malang.

Jamaica Association for the Deaf. (2015).

Empowering Deaf and Hard of Hearing Persons to Help Build Our Nation. Diakses dari https://www.jamdeaf.org.jm/ pada 7 November 2021.

Rahmawati, F. 2012. Pendidikan Seks untuk Anak Autis. Jakarta: PT Elex Media Komputindo.

Reid, G. (2011). Dyslexia. London: Continuum.

Schultz, P. W., \& Estrada-Hollenbeck, M. I. C. A. (2008). The Use of Theory in Applied Social Psychology. Applied Social Psychology. Cambridge University Press, Cambridge, 28-49.

Slavin, R. E. (2006). Educational Psychology. Theory and Practices. Boston: Pearson Allyn and Bacon.

Sugiyono. (2016). Metode Penelitian Kuantitatif, Kualitatif, dan $R \& D$. Bandung: PT Alfabeta.

Viramitha, Kusnandi Rusmil et al. (2016). Hubungan Perilaku Ibu dalam Praktik Pemberian Makan pada Usia 12-23 bulan dengan Kejadian Stunting di Wilayah Kerja Puskesmas Jatinangor. Jurnal Sarupediatri Vol. 20 No. 6. 